\title{
Landscapes for Conservation of Biological Diversity with Focus on the Northern Western Ghats of Maharashtra (NWGM)
}

\author{
Vishwas Sawarkar \\ (The author retired as Director, Wildlife Institute of India, Dehradun and \\ is Trustee, The Ecological Society, Pune)
}

\begin{abstract}
National wellbeing is dependent on the productivity of its lands. Productivity is central to the interest of natural ecosystems and the systems of farming. Water is essential for sustaining life, for ensuring food security as well as for effectively driving all development projects. Security of water is ensured by secure natural ecosystems centered on biological diversity. The terms productivity and biological diversity are synonymous therefore it is essential for all processes and projects of development to internalize the security of biological diversity/natural ecosystems. The principle at present however is almost non-existent in all development programmes because had it been so the forest and environmental clearances would not be considered loud and clear as hurdles to development. Western Ghats are one of the ecological hotspots of the world. The northern Western Ghats have diverse forests, protected areas, ecologically sensitive areas declared under law, ecologically sensitive tehsils and villages and sacred groves managed and maintained by local communities. There are significant catchments and watersheds, origins of important rivers, many springs and lateritic plateaus with unique species assemblages that are characteristic only of the northern Western Ghats. These units together constitute the foci of conservation of natural ecosystems. The tract has several dams and the largest hydroelectric facility. It supports diverse economies including the most rapidly growing tourism industry with many visitor destinations and famous hill stations dotted across these mountains. In order to ensure ecological security of these fragile mountain ecosystems it is necessary to address land use at the largest spatial scale recognized as the landscape. Landscape allows using the disparities within its constituents - the mosaic of interacting land uses by creating opportunities for reducing their inter se contradictions. The paper discusses such opportunities and strategies at various spatial scales.
\end{abstract}

Keywords : western Ghats, Forests in India, Landscape-based conservation, Protected Areas in India, Ecosystem-based Management

\section{Introduction}

There are two categories of land uses in the class of renewable resources in which productivity of the land is central to the objective of management. These are forests and agriculture lands. The recorded forest area (RFA) of the country - the lands under the control of the forest department - is $771821 \mathrm{~km}^{2}$ or $23.48 \%$ of the country's geographic area[1]. An estimated $50 \%$ of the country's geographic extent is under farming of some kind or the other. Forests are natural lands managed for production of goods - ranging from timber of varied qualities to a formidable list of non-timber forest produce (NTFP) that support the livelihoods and economy, cultural security and spiritual needs, and significant support to human and livestock health (ethno medicine and the processed and patented drugs) of many millions of forest dwelling people. While that is so, forests are also critically important for the wellbeing of the millions who live on lands that are far removed from the forested regions, including those urban areas that are completely transformed in character and counted towards the pillars of economic growth and national progress.

Natural ecosystems provide a host of services that include at least five that are critical for the wellbeing of the nation - soil and water security, amelioration of climate, food and economic security. Besides those forest areas that serve production functions an estimated $20 \%$ of the RFA is under the network of 
Protected Areas (PAs) - national parks, sanctuaries, conservation reserves and community reserves[2]. The most important fact about the RFAs is that the lands are highly fragmented with variable patch sizes located in a large matrix of incompatible land uses which has resulted in steep challenges for their conservation - unremitting biotic pressures leading to degradation, the increasing demands of the development sector, politics of various kinds and shades and the interplay of the principles of the science of insular biogeography made harsher by the former three.

Agriculture is an artificial or man-made ecosystem whose productivity is measured in terms of the yield of a given farm produce per hectare. Fundamentally agricultural productivity is dependent on the status of soil richness (nutrients, structure and depth) and security that natural vegetation in the region provides. Farmers enhance or replenish soil richness by application of fertilizers and by protecting crops from pests by using insecticides. Along with the quality of soil the other essential in support of productivity and sustainability of produce is water. Apart from the seasonal rainfall and its fluctuations the agriculture system is dependent upon the forests for recharging the enormous reserves of ground water via the forested catchments of rivers and streams.

There is a third category of land use that although belongs to the non-renewable resource class it is critical for being considered in the big picture of conservation of natural ecosystems and their sustainable use since its negative influence looms large over the fate of the two renewable land use categories. Most land uses in this category also consider productivity as central to their interest; however its measures would not be considered here since only the natural renewable resources - mainly forests out of the two in the category are under focus. These land uses in the non-renewable resources category are made up by different development programmes and activities. Construction of all kinds and setting up industrial units, power plants, dams and other infrastructure form the bulk of these programmes. Although considerable raw material is mined and processed for the purpose including imports that are all non-renewable, there is heavy dependence on water. Water is considered a renewable resource because of its replenishment by the annual monsoon. The forest and other natural vegetation - all natural ecosystems - are critically important as insurance for charging ground water reservoirs, maintaining the life of dams by keeping siltation at normal rates and ensuring maintenance of intended water levels; keeping alive the flow of water in rivers and streams called water quantity, quality and regime. The development sector most certainly is extremely important but in terms of its attitude and actions - of being considered the last word for national progress - it neglects the security of natural ecosystems that provide many critical services on which development is totally dependent.

All evidence suggests that conservation of natural ecosystems is considered a hindrance to development by a contrived interpretation that conservation is all about locking the 'green' areas and throwing away the key. This is completely at variance with the true meaning of the term conservation including its operational imperatives.

India like many countries in the world faces threats from natural calamities like cyclones, floods and droughts. There is sufficient proof now that effective conservation of natural ecosystems prevents such threats from turning into disasters or if disasters happen in reducing their impacts because of the natural resilience of ecosystems and their capabilities for recovery. The Oxford Dictionary defines the term conservation as - the act of preventing something from being lost, damaged, wasted or destroyed - by all accounts it means 'wise use' or in its differently worded and frequently used form 'sustainable use'. What is the measure of sustainability depends on the nature of the resource, its value and status therefore it must be so defined by the standards of widely established modern ecological principles.

The ecological definition of productivity for the natural lands like the RFA and other natural ecosystems outside the RFA is 'the capability of the soil for producing the full range of native plants at the specified geographical location'[3]. It is a long established fact that evolution of plants is mediated by the inseparable interactions between plants, animals and their abiotic environment. The debate about which came first - plants or animals is similar to the debate about the chicken and egg. Ecologists define plants as primary and animals as secondary productivity, however for the purpose of conservation there is little option but to define productivity as 'the capability of the soil for producing the full range of native plants and animals at the specified geographic location'.

Biological diversity is popularly interpreted as the numbers of species in a given area which is incorrect and such kinds and numbers actually refer to species richness while the widely accepted definition of 
biological diversity is 'the variety and variability of life forms, the interacting processes and functions' [4]. The interacting processes involve those between the life forms and between the life forms and the abiotic environment. Thus biological diversity and productivity are synonymous. Any other measures that narrow it down to the needs of a particular produce/product under the term 'productivity' needs to be considered as a subset of true productivity with sustainability as the linchpin of its use. It will thus be observed that conservation of biological diversity is not confined to the attention on species of plants or animals alone - important as these are - but refers to a very complex world of ecological processes, functions and services many of which are unknown or poorly understood.

\section{Conserving biological diversity}

Conservation of biological diversity is viewed primarily through protected areas (PAs). The National Forest Policy 1988[5] refers to these as such and the Wildlife (Protection) Act 1972 has provided the teeth to protect and conserve these areas inter alia tying together their constituents, a range of species that are listed in its Schedules and laying down provisions for securing their habitats. There currently are four categories of PAs legally recognized in the country National Park, wildlife sanctuary, conservation reserve and community reserve. There is a fifth category of Biosphere Reserves (BRs) not yet legally recognized as a PA category[6].

The IUCN recognizes six categories of PAs category (Ia) Strict Nature Reserve set aside to protect biodiversity and also geological/geomorphological features, where human visitation, use and impacts are strictly controlled and limited to ensure protection of the conservation values. Such protected areas can serve as indispensable reference areas for scientific research and monitoring; ( $\mathrm{lb})$ Wilderness Area, usually large unmodified or slightly modified areas, retaining their natural character and influence without permanent or significant human habitation, which are protected and managed so as to preserve their natural condition -these two categories are absorbed in India's National Parks and sanctuaries with appropriate zones to protect such values. The BRs also serve those objectives.

The IUCN Category (II) includes National Park and by its definition the sanctuaries in India also to a large extent fulfil the purpose of this category. IUCN category (III) represents Natural Monument or Feature set aside to protect a specific natural monument, which can be a landform, sea mount, and submarine cavern, geological feature such as a cave or even a living feature such as an ancient grove. They are generally quite small protected areas and often have high visitor value. India does not have this category of PA. Category (IV) represents Habitat/ Species Management Area to protect particular species or habitats and management reflects this priority. This category fits into specific areas of national parks and sanctuaries in India where such objectives have been set. The GIB sanctuary in Solapur district is an example.

Category (V) is for Protected Landscapes and Sea Scapes where the interaction of people and nature over time has produced an area of distinct character with significant, ecological, biological, cultural and scenic value and where safeguarding the integrity of this interaction is vital to protecting and sustaining the area and its associated nature conservation and other values. This category is mostly in the domain of a priority management concept. The countrywide assessment of the status of the tiger, co-predators, prey and their habitats undertaken every four years by the National Tiger Conservation Authority (NTCA) and the Wildlife Institute of India (WII), Dehradun recognizes five landscapes and their sub-units. The information generated is used for conservation action and to an extent for preparation of the Tiger Conservation Plans (TCP). Conservation of the coastal and marine ecosystems requires the use of such big picture that connects with terrestrial landscapes.

Category (VI) bears the title 'PA with sustainable use of natural resources'. The BRs are based on such philosophy with a difference that these within their large extent include some PAs such as national parks and sanctuaries. The conservation and community reserves that are the other legally recognized PAs besides the national parks and sanctuaries fit into this IUCN category. Portions of many PAs in future might fit into this category in context of the settlement of rights under the Schedule Tribes and Other Traditional Forest Dwellers (Recognition of Forest Rights) Act 2006 (FRA). Considering the large numbers of villages in many PAs, and with the paucity of funds to relocate those that have volunteered for relocation outside PAs many villages are likely to remain within PAs with such people's rights to lands and resources settled in favour of individuals and communities.

On practical considerations Category (V) and (VI) share several purposes that include the Reserve Forests, Protected Forests, and other categories of 
forests - the Recorded Forest Lands (RFA) as defined by the Forest Survey of India - under the stewardship of the forest department. These tracts represent various ecosystems, habitats, wild species, communities, populations and ecological services[7,8].

The World Heritage Convention proclaimed by UNESCO has added World Heritage Sites and World Heritage Sub-clusters as a category of PA. PAs that meet the criteria can qualify for such status plus those that are not PAs can also feature in these[9].

\section{Assessing, measuring and conserving biological diversity}

Biological diversity is assessed and measured at five scales - genes, species, communities, populations, ecosystems and landscapes. These in a sense constitute a design of nested scales with genes as the smallest of these at the micro scale to be assessed and measured by scientists in a laboratory to determine among the vast numbers of outcomes the environmental fitness of a species by the measure of genetic variability of its population which in turn predicts the future of the species[10,11]. This provides options for undertaking the appropriate conservation interventions. For the manager in the field the visible manifestation of biological diversity is by species, communities and populations of wild plants and animals by the size and distribution. There is a wide range of techniques for their assessment and measurements. The ecosystem as a concept is not difficult to comprehend but ecosystems are not easy to assess and measure because of their fluid and merging boundaries and of their different components some of which might qualify to be identified as independent systems. Landscapes being clearer spatial units are amenable to setting boundaries and constitute the largest of the five scales.

PAs are central to the conservation agenda. The tiger reserves in India include one or more categories of PAs. The features of the Tiger Conservation Plan (TCP) as set out in the Wildlife (Protection) Act 1972 and the NTCA's guideline for the purpose[12] integrate all the important elements - biological, ecological, cultural, social and economic - that are essential for effective conservation of natural ecosystems. The WII's guide for planning wildlife management in PAs and managed landscapes also in various details contributes to the cause[4]. Therefore there appears to be no dearth of scientific precepts, capabilities and strategies that could be based on ground realities. What is lacking is the enabling push that is dependent on integrated mechanisms - appropriate policies, laws, regulations and programmes that could be resolutely enforced -'the big four' - that can deliver rather than pontificate - by involving the agenda of many ministries and departments of the government and where lies the rub.

Many elements of the 'big four' are already in existence. There are laws like the Wildlife (Protection) Act 1972[6], the Environment (Protection) Act 1986[13], the Forest (Conservation) Act 1980[14], the Biological Diversity Act 2002[15], the Wetland Conservation and Management Rules 2010[16] and the Coastal Regulation Zone Notification 2011[17]. There are policies such as the National Environment Policy 2006[18], National Forest Policy 1988 and the Marine Fishing Policy 2004[19]. There are national strategies and action plans such as National Conservation Strategy and Policy Statement for Environment and Sustainable Development, 1992[20]; National Wildlife Action Plan 2002-2016[21], National Biodiversity Strategy and Action Plan, Guidelines and Concept Papers, 2000[22]. There are guidelines Guidelines for Protection, Maintenance, Research and Development in the Biospheres Reserves in India, 2007[23], Guidelines for Integrated Management Action Plan for Wetlands, Mangroves and Corals, 2009[24]. Although the State Boards of Wildlife and the National Board for Wildlife strive towards strengthening the PA management and conservation of coastal and marine ecosystems, the coordination between the line departments remains a steep challenge. They are split horizontally along their sectoral agenda and have little willingness or mechanisms to synergise the actions towards attainment of the national ecological goals expressed by laws, policies and action plans.

Individually the elements are excellent but there is no overarching direction within the national agenda to ensure synergy and coordination between the programmes of all government agencies under the essential common frame of reference, that for the security of natural ecosystems.

India has a network of 658 PAs (all categories) covering $158,745 \mathrm{~km}^{2}$ or $4.83 \%$ of the country's geographic area and some $22 \%$ of the RFA. Out of these only 23 PAs are $>1000 \mathrm{~km}^{2}$ in extent[4]. The average PA size works out to $<300 \mathrm{~km}^{2}$, which is too small to accommodate the range of habitat attributes, and thus native biological diversity at the given geographic location or to contain sizes of environmentally fit populations - those with a wide base of genetic variability - of the wide ranging 
species and others that need more space with uncertainty about how the processes of recruitment and mortality within populations of various species plants not excepted - would affect their future. Simply stated the principles of species-area curve apply. Further PAs appear mostly as insular habitats in a matrix of non-compatible land uses. The conservation capability of PAs, the size apart is determined by their shape and the degree of isolation from other habitats, likewise by their capability for withstanding the impacts of random natural events and the high intensities of biotic pressures that they are subjected to. The sizes of PAs are extremely difficult to increase, not necessarily because for the want of suitable habitats but because of the legal restrictions on uncontrolled use of such lands. Because of this the local communities strongly resist such move. Lack of political will to translate the benefits of protected areas is also a serious hurdle. Likewise any process for creation of new PAs is severely objected to.

PAs because of stricter laws and their enforcement are expected to serve the function of source areas i.e. the rates of recruitment into wildlife populations are expected to be higher than the rates of mortality thus producing a surplus of individuals that are ordained to disperse to suitable habitats according to the laws of evolution which have already been proved. Since the habitats outside the PAs are penumbral and beset with many other problems these are sink areas i.e. the rates of recruitment into the wildlife populations are lower than the rates of mortality causing decline of species and populations. The wisdom of conservation lies in linking source areas with sinks to balance the negative pulls of the latter and thus make it possible to maintain 'large' interacting populations of various species called metapopulations over large geographic areas. Dispersal corridors connecting PAs and other existing and potential habitats of various attributes are critical pieces of this jigsaw[25].

Forests outside the PAs are managed to produce various goods and services some of which that are degraded are set aside for the purpose of restoration. Those forests with potential for producing high quality timber and non-timber forest produce (NTFP) are designated for production functions. The kinds of timber and NTFP depend on geographic locations and forest types. For example the timber in Himalayas includes deodar, spruce, fir and pine in the coniferous forest types. The NTFP includes walnut and chilgoza among the large numbers of others. In the dry deciduous forest type of central India teak and sal are the main timber species. The NTFP includes char or charoli and amla. It needs to be remembered that whatever the geographic location the list of NTFPs is extensive and what is cited here is a small example[26]. Although the wisdom of science and the system of techniques employed for managing forests might not always be understood by lay persons these can also be used to maintain, alter or create habitats (for maintenance of biodiversity) of various attributes and extent $[27,28]$. Thus it is possible to improve the quality of sinks and even change some sink areas into source areas. The forest department alone cannot accomplish this because of the great pressure of the rural and semi-urban sectors on the forest resources. In order to address these pressures the poorly supported and funded forest department is heavily burdened with community welfare programmes. The way out is for the large numbers of other departments charged with the welfare of people under various programmes must serve the needs of people effectively according to their mandate. This would greatly help in providing alternate livelihoods and other economic opportunities to rural communities to reduce the pressures on the forests and allow the foresters to do their job for which they are trained which management of natural ecosystems is.

To summarize the sciences of Insular Biogeography, Conservation Biology and Landscape Ecology provide the largest evidence in favour of managing biological diversity at landscape levels that includes PAs as their crucial sub-units.

\section{Significance of Landscapes}

A landscape is defined as 'a mosaic of interacting land uses with people and the impacts of their activities integral to it'[4,29]. Landscapes can have an extent of several thousand square kilometers. The interactions across and between land uses are expected to be many and complex including the positives and the negatives interpreted and centered on the short term interest of people. For attaining conservation goals sustainability of land based activities is essential. This is possible only with an integrated approach where all departments honour their mandates. Sustainability obviously implies the ecological connotation and principles that must have the highest priority - security of natural ecosystems through good practices those inevitably lead to equitable benefits shared by people - however disparate the nature of objectives of such land uses might be.

Tomes are written on the benefits derived from natural ecosystems by human societies with little or 
no quid pro quo. The problem is that the benefits are not allowed to be understood by the interplay of politics and secondly the benefits are taken for granted and therefore find few or no advocates in places that make the difference in favour of conservation of ecosystems. It is unfortunate that politics of economy and development is based on populism. Since it is also based on attaining short term gains it is not surprising that ecological services that work on the scale of long term benefits are put at a great disadvantage. Environmental and forest laws are routinely blamed as representing legal 'hurdles' that stand in the way of 'development'. Absence of patience and willingness to understand the value of ecological services has led to heavily distorted arguments that emphasize that environmental and forest laws are against citizen's interests and that more value is placed on wildlife than on human life. The absence of priority for the security of natural ecosystems is evident in the national denial of the most dreaded force of climate change and its consequences for the wellbeing of the country[30]. The episodes of droughts, excessive rainfall, floods and cyclonic weather at different geographic locations during the past many decades have now become all too frequent. The only answer to contend with these is to respect ecological integrity through measures and efforts of all organs of the government. This will not guarantee reduction of such episodes in quick time since climate change has a global presence and it has been building up since the beginning of the Industrial Age, for the past some 250 years and therefore will need time while the human population of the world keeps rising at an alarming rate.

According the top priority to conservation of natural ecosystems does not mean any conflict of interests because the most important objectives of governance - ensuring the quality of human life and the wellbeing of the nation - the pillars of India's Constitution- necessarily ride piggyback on productive natural ecosystems. Ensuring security of natural ecosystems does not mean making sacrifices and befriending privations. It is about using modern technology and designs to reduce impacts to the minimum acceptable - both ecological and social. It is about necessarily being prepared for adopting relatively expensive but efficient alternatives that integrate the concerns for natural ecosystems and environment in lieu of those traditions that are impactive and used for maximizing profits. Above all in context of good governance it is about communicating the ecologically and economically correct signals to the constituencies of disparate political leanings without fear or favour. This approach undeniably implies a price required to be paid during the present for ensuring the future wellbeing of the country.

\section{The approach to conservation of landscapes}

There could be several approaches for setting boundaries for landscapes: (i) maximizing inclusion of forest types with special consideration to those that are most fragile - such as the rainforests; dry and moist grasslands, those that are rare and isolated, those bearing the brunt of human activities; areas of significant catchments and a scatter of wetlands, swamps, bogs, patches of primitive plants, rocky plateaus (ii) attempts at including populations of wide ranging species on account of their physical and behavioural attributes - of being large bodied, of those territorial/having large home ranges, those with seasonally separate geographic ranges, of species that are rare, populations that are small and scattered or those geographically restricted, and species that are habitat specialists - coincidentally almost all of such species would be in various categories of 'threatened species' or the other; (iii) including areas with potential dispersal/movement corridors connecting habitat patches within a landscape critically important to maintain the balance between the source and sink areas[31].

Natural drainages also called riparian systems are the most effective corridors because they run across and along contours with a dendritic pattern thus connecting all habitat types and patches along altitudinal gradients[32]. These need not have vegetation all along their length nor need they be perennial. A patchwork of vegetation and scattered pools of seasonal or perennial sources of water such as springs could serve the purpose excellently. Likewise outside the riparian systems a patchwork of vegetation, or scattered piles of large boulders depending on inter patch/inter pile distances these can serve as effective corridors working like dispersal routes paved with stepping stones. Most larger species can thus travel along these. Tall crops in agriculture areas, patches of horticulture farms that are conveniently located, and ravines are other features that allow movement of wild animals to reach large habitats. Some species overcome the risk of 'visibility' during travel by travelling long distances at night. Some species like the leopard are adapted to using minimal cover and thus can 'hop' considerable distances without being detected or disturbed. In 
summary, corridors need to have features that offer security, concealment and some water. Large carnivores opportunistically feed on livestock as they move. Herbivores seek food in patches of natural vegetation encountered or in farm crops to tide over their needs while on the move[4].

Within the circumscribed boundaries of a landscape the most important legal and administrative units - depending upon their geographic location - are made up by the maximum of four legal categories of PAs and tiger reserve/s with their buffer zones along with RFAs outside the PAs all managed by the single agency of the forest department. There also could be areas declared as Ecologically Sensitive Zones (ESZ) also sometimes called Ecologically Sensitive Areas (ESA), a legally mandatory requirement under the Environment (Protection) Act 1986 around national parks and sanctuaries[40]; may be a BR as well. There also could be ESA/s that are declared independent of PAs and managed by different agencies with the forest department being one of those. These categories of lands are expected to be in shape of fragments within a large matrix of disparate and non-compatible land uses including human settlements of various sizes and numbers.

The only way to attain the objectives of conservation of landscapes - those of securing the interests of ecosystems and their services currently addressed by only a single agency, the forest department which is placed on the lowest rungs of importance among all government agencies because of being considered inconsequential in the same manner as the natural ecosystems - is through the convergence of multi- agency programmes of various ministries and departments of the government, especially those that ostensibly serve the welfare of people in rural India. The fivefold agenda at the forefront with emphasis on rural areas needs to include quality education with access to the best teachers and institutions; a vista of vocations and work opportunities; safe drinking water and its delivery to all; effective support of energy; hygiene in its true sense and sensitive healthcare. This would progressively reduce the rural community's direct dependence on forest/natural ecosystem based resources. The sectoral walls of different departments protecting their turfs continue to stand and grow stronger. The existing instruments that can help in management of landscapes are stated later. The first step in getting the 'big four' working is to undertake institutional mapping.
There are a plethora of agencies working for various purposes, sometimes at cross purposes at the levels of the Center, the States, and districts and down to the Panchayati Raj Institutions (PRI). Further there are civil societies with a large canvas of separate as well as overlapping agenda. These all are or supposed to be stakeholders in national interests. While mandates and priorities might be different there also are areas of overlaps, therefore this becomes a problem in getting all on the same page. Coordination is the biggest challenge. It is important to know who is mandated with what and the mechanisms of actions. Institutional mapping has six categories of functions under which various authorities, agencies, departments can be classified. They are : (a) those that have jurisdiction over the resources: e.g. the forest department, the revenue department, the department of fisheries, department of atomic energy, power, tourism, urban development (b) the regulatory arms: e.g. police, forest and revenue departments, municipality/municipal corporation (c) agencies with repository of knowledge and data : e.g. revenue/land records; forests; meteorology (d) agencies with functions for development: e.g. power, atomic energy, fisheries, national highways authority; municipality/municipal corporation; tourism (e) regulatory users: e.g. hotels and hospitality (f) political authority for decision making: e.g. the municipality/municipal corporation; PRI; parent ministers for districts (UNISDR/UNDP 2012). This is only an illustrative list[33].

\section{The Northern Western Ghats of Maharashtra (NWGM)}

The Western Ghats feature among the world's 34 Biodiversity Hot Spots[34]. The estimated area of Western Ghats varies from $130,000 \mathrm{~km}^{2}$ to 180,000 $\mathrm{km}^{2}[35,36$ and 37]. The most often quoted figure is $160,000 \mathrm{~km}^{2}$ or $4.8 \%$ of India's geographic area. The limits are not precisely delineated hence some different versions could also exist. The Western Ghats run north to south over a distance of $1600 \mathrm{~km}$ along the western edge of the Deccan Plateau from the river Tapi where the Satpuras end through to Tamil Nadu. The state wise area of the Western Ghats and percentage to the total geographic area of the states/ UT concerned in which they feature are Gujarat (4400 $\mathrm{km}^{2} / 2.2 \%$ ), Union Territory of Dadra and Nagar Haveli (100 km²/24\%), Maharashtra $\left(54000 \mathrm{~km}^{2} /\right.$ $17.54 \%)$, Goa (3770 km²/99.9\%), Karnataka (45200 $\left.\mathrm{km}^{2} / 23.5 \%\right)$, Kerala $\left(38800 \mathrm{~km}^{2} / 99.8 \%\right)$ and Tamil Nadu $\left(12900 \mathrm{~km}^{2} / 9.2 \%\right)[1]$. The total extent of the 
Northern Western Ghats (NWG) - three states and one UT - is $62,270 \mathrm{~km}^{2}$. The NWGM area accounts for $86.71 \%$ of the NWG and $33.75 \%$ of the total extent of Western Ghats. Thus it is a very important tract of this mountain chain. The average elevation of Western Ghats is $1200 \mathrm{~m}$ ASL. The northern Western Ghats up to Goa are formed of massive horizontal beds of Deccan trap. These present vertical profiles of $1000 \mathrm{~m}$ and more along the successive series of beds that are scenically extraordinary. Around Goa the height of the Western Ghats is abruptly reduced to about $650 \mathrm{~m}$ ASL but after Honnavar the height is regained with steep sides all around. The tallest peaks are found in this region. At $2695 \mathrm{~m}$ height, Anamudi in Idukki district of Kerala is the tallest peak in the Western Ghats. Kalsubai $(1646 \mathrm{~m})$ in Maharashtra is the highest peak in northern Western Ghats[38].

In terms of research thus far most attention has been focused on the Southern Western Ghats, more mountainous with many high peaks, high diversity and important catchments. This however does not diminish at all the importance of NWGM.

\section{Forest Types}

According to the system of classification of forest types by Champion and Seth[39] the NWGM is represented by seven sub-groups and 11 sub-types (Annexure I) as the major habitat types. Depending on species-habitat relationships these represent a large number of specific habitats within the forest sub-types in addition to those that are outside the system of classification.

\section{Biogeographic Classification}

According to the biogeographic patterns India is classified into 10 Biogeographic Zones. These are large distinctive units of similar ecological conditions, biome, communities and species representation. These have further 27 sub-units recognized as Biotic Provinces - secondary units with weightage to specific communities (vegetation and animals) separated by barriers to dispersal or gradual change in environmental factors. The Land or Landform Region constitutes tertiary units within a province indicating different landforms. The Biome is an ecological unit such as swamp/wetland or a dry deciduous forest that could be found in many Biogeographic Zones and Provinces. These can be equated to Champion and Seth's system of forest classification in addition to non-forest categories such as wetlands, the coastal and marine systems. The framework has expressly been established to ensure that each biogeographical unit including the subunits is represented by PAs. The PAs in NWGM represent the Biogeographic Zone 5Western Ghats with its two Provinces - 5A : Western Ghats Malabar Plains and 5B: Western Ghats Mountains[2,35].

\section{The core conservation landscape units}

Land units such as the PAs, BRs, tiger reserves (TRs), the Reserve (RF), Protected (PF) and other categories of forests including private forests, Eco Sensitive Zones, and sacred groves constitute the core conservation areas on account of specific laws, rules or by their social/cultural and religious significance. Rocky plateaus characteristic of NWGM form a category that is very important and unique in its ecological characteristics. Catchments/watersheds not in the PA and forest land categories and significant floodplains including riparian zones and patches also need to be added to these as areas that provide critical ecological functions and are sensitive to disturbance. At the scale of microsites there are ecologically fragile and significant elements for maintenance of biological diversity and ecological services. These are - springs, seeps, bogs, swamps and marshes, wetlands, natural grasslands/grassy openings, patches of rocky outcrops, ravines, caves, dens, cliff faces, overhangs, ledges and cliff tops, wallows, and natural saltlicks. There are microhabitats of biological origin that are essential for many species. These are snags, hollow live trees (den trees), large crowned isolated old trees, old groves, large climbers and fallen large trees decomposing slowly[4].

The NWGM has 7 sanctuaries aggregating an area of $1593.54 \mathrm{~km}^{2}$ but has no national park. As per the national recommendation however there are new proposals to create 2 national parks - Radhanagari and Koyna, each with an extent of $150 \mathrm{~km}^{2}$ to be carved out of the existing sanctuaries bearing the same names and 5 small sanctuaries extending over 135.52 $\mathrm{km}^{2}$. The $732.52 \mathrm{~km}^{2}$ Sahyadri tiger reserve with inclusion of the Koyna and Chandoli sanctuaries is the single tiger reserve in this area[2] (Annexure II). It is mandatory to identify and declare Eco Sensitive Zones around national parks and sanctuaries. The Government of India in MoEF has issued guidelines for declaration of such ESZs[40].

Conservation of PAs is accomplished through management plans. The Ministry of Environment and Forests (MoEF), Government of India (GoI) does not release funds under its centrally sponsored scheme for management of PAs unless there is an approved and current management plan in place for a PA. There is a 
detailed process for preparation of these plans and covers all stages of planning for which a guide exists[4]. The mere existence of a plan is not so important as its relevance, quality and application of prescriptions that are on track. Monitoring the application of plan prescriptions, taking remedial actions on setbacks and backlogs even if these are required to be addressed subsequently are crucial aspects and part of the process. Tiger Reserves are likewise mandated to be managed by plans called the Tiger Conservation Plan (TCP) as prescribed under section 38V of the Wildlife (Protection) Act 1972. The National Tiger Conservation Authority (NTCA) has established a guideline for preparation of the TCPs as stated earlier.

The three important sanctuaries in the NWGM are Radhanagari to the south and Chandoli and Koyna to the north. The distance between Radhanagari and Chandoli is approximately $60 \mathrm{~km}$. These three PAs together with the patchwork of intervening forests, two large dams and several small ones form a landscape unit, some $1600 \mathrm{~km}^{2}$ in extent that forms a part of four Forest Ranges - Panhala, Gaganbavda, Pendakhale and Malkapur. The tract has many scattered perennial springs forming small pools of water down the slopes. The connectivity or the corridor between Radhanagari and Chandoli is along the Crestline defined by several flat rocky plateaus that might appear bare of vegetation during summer except for small groves of typically stunted trees festooned with moss. During the rains and winters these plateaus are covered with many species of grasses, herbs and small shrubs. As per a survey conducted in the landscape during 2007 it was estimated that the area has a potential for supporting a population of 20 tigers. The survey listed seven sites that need to be managed as mini core areas - Udigiri $\left(95 \mathrm{~km}^{2}\right)$, Amba $\left(160 \mathrm{~km}^{2}\right)$, Gelavade dam to Anuskura $\left(51 \mathrm{~km}^{2}\right)$, Barki $\left(27 \mathrm{~km}^{2}\right)$, Vashi-Padasali $\left(43 \mathrm{~km}^{2}\right)$, Kode-Asraf-Wesraf $\left(57 \mathrm{~km}^{2}\right)$ and GaganbavdaPadmasetti $\left(70 \mathrm{~km}^{2}\right)$.

Unregulated tourism in the Amba area and unregulated firewood extraction by people from Amba and Manoli for supply to some 20 tourist resorts is a grave threat, particularly since the Radhanagari-Chandoli corridor is barely $500 \mathrm{~m}$ in width along most of its extent. The connectivity north of Chandoli to Koyna has a much better status[41].

The World Heritage Convention of UNESCO has inscribed a World Heritage Sub-cluster in the NWGM among those in addition to the southern tracts of the Western Ghats. This includes the Sahyadri sub-cluster with four site elements located in Maharashtra and includes the Kas plateau with unique ephemeral floral features, the Koyana, Radhanagari and the Chandoli sanctuaries. Eight main rivers along with numerous tributaries flow out of this region. Besides there are catchments of 8 dams including the largest hydroelectric dam in the Western Ghats on the Koyana River[42]. The National Register of larger dams of India reveals the existence of 165 dams in the region of NWGM[43]. This suggests the critical need for protecting their catchments and watersheds.

The Forest Survey of India (FSI) states the forest cover extent in the Maharashtra's Western Ghats (NWGM) at $18966 \mathrm{~km}^{2}[1]$. The report states loss of area under dense forests category which has increased the area (by transfer) under the medium-dense and open forests categories. This indicates that the forests are under great deal of pressure. The causative factors can be varied-from local community dependence on resources to 'development'.

The Pune based Wildlife Research and Conservation Society (WRCS) in its report of 2013 on the status of private forests in the northern Western Ghats[44] have estimated the extent of private forests at $12043 \mathrm{~km}^{2}$ of which $6020 \mathrm{~km}^{2}$ are under tree cover while the remaining area is in the category of scrub and open forest. An area of $5794 \mathrm{~km}^{2}$ of private forests is vested in government (forest department). Uses of these forests include felling of trees for firewood for household use as well as for sale; lopping for rab burning (lops and tops of trees spread across cultivation area and setting it on fire to prevent regeneration of weeds and to enrich the soil by minerals released in the ash); pasture and for shifting cultivation. Kolhapur district is among three districts that show poor quality private forests. Soil erosion is commonly seen and larger threats include sale of land to businessmen, for construction of resorts and farm houses, conversion to plantations of coconut, banana, rubber and pineapple. The findings indicate that there is loss of forest cover as well as significant tracts are under degradation. Considering the acknowledged fragility of the WG there is urgent need to remedy the situation.

The recorded forest cover of NWGM is made up by 12 Districts of which some have $>50 \%$ of their areas in the NWGM and some have $<50 \%$. The district wise forest cover is depicted under Annexure III. However since the areas of partial inclusions in NWGM could not be ascertained the figures are higher than those reported by FSI[1].

The flat plateaux of the northern Western Ghats 
have evolved from intense physical and chemical weathering of basalt flows, often exposed with thin soil cover. The annotations on topographic maps often identify these features as 'rocky scrub', 'stony waste' or 'sheet rock'. Since the plateaux have poor vegetation cover, especially of trees they appear as open spaces in satellite imageries. The Wasteland Atlas of India by the NRSA and Ministry of Rural Development show extensive tracts under category 22-barren, rocky, stony waste areas in the NWGM. In reality the rocky plateaux have high biodiversity values. The 'waste land' status conferred on them makes these plateaux highly vulnerable to exploitation for activities that work against their ecological fragility. High level ferricates are located between $800-1400 \mathrm{~m}$ ASL along the crest line of the NWGM in Kolhapur, Satara, Ratnagiri andSindhudurg districts but not south of it. Thus these geological-ecological features are restricted in their distribution. Their conservation values are based on a study at 67 locations in 6 districts of Maharashtra. Thus far 188 species of endemic plants have been recorded on the rocky plateaux and though many species are not exclusive to the rocky plateaux, these features serve as habitats for a large number of endemic species. It is acknowledged that rocky outcrops make a significant contribution to the local and regional species richness. High endemism and recent records of many new endemic species in disparate taxa from the rocky plateaux (67 sites) indicate high conservation significance. The ecosystem services are often neglected in making decisions on land use because these are free and taken for granted. Specifically about the rocky plateaux-they serve as water catchments. The lithomarge promotes underground water channels that are expressed as springs along and below the plateaux. Seasonal mass blooming of plants offers abundant food for the pollinators. This is important for crops and orchards in the surrounding areas at the appropriate time[45,46].

There are four independently notified Environmentally Sensitive Zones within the NWGM under section 3, subsection (1) clause (v) of the Environment (Protection) Act 1986. These are (i) Mahableshwar-Panchgani region covering $237.28 \mathrm{~km}^{2}$ with details of its administrative units, villages, the forest zone and the green zone[47] (ii) Matheran and surrounding region of $214.73 \mathrm{~km}^{2}$ with a buffer zone of $200 \mathrm{~m}$ all around the area. The inclusions are likewise detailed[48]. Both of these regions are required to be managed under their respective Zonal
Master Plans. The expectations and conditions are specified. A high level monitoring committee for each of these regions has been appointed to ensure the implementation of actions and regulations (iii) Dahanu taluka of Dahanu district is declared as an ecologically sensitive and fragile area and in line with the concern there are restrictions imposed on setting up industries which have detrimental effect on the environment. The industries are classified as Red, Orange and Green categories. The regulations and actions are enforced through a Master Plan/Regional Plan with the expectations spelled out[49]. (iv) In Murud-Janjira area of Raigadh district there is prohibition on locating all industries carrying on operation or processes in a block of one kilometre from the high tide mark of Revdanda creek up to Devgarh Point near Shrivardhan as well as in a one kilometre belt along the banks of Rajpuri creek up to Mhasla except those industries that promote tourism and those permitted by the Central Government after the due process of EIA[50].

There are 67 sacred groves within the NWGM[51]. The largest near Kolhewadi village in Junnar taluka of Pune district has an extent of 263 hectares while the smallest of 12.04 hectares is near Bidwad village, Kankavli taluka of Sindhudurg district.

There are two reports namely of the Western Ghats Ecology Expert Panel (WGEEP)[43 and 52] and by the High Level Working Group on Western Ghats (HLWG) [53 and 54]. Both these reports have been nationally commissioned. These are widely disseminated and need no introduction. Only the cogent content as relevant to the ecological fragility of the WG in general and NWGM in particular are cited. These are quoted mostly verbatim.

\section{The report of WGEEP}

The WGEEP has adopted 3-layered approach and attempted to assign relative levels of ecological sensitivity to areas based on 8 parameters using $9 \times 9$ $\mathrm{km}$ or $5^{\prime} \times 5^{\prime}$ grids. WGEEP recognized Three Ecologically Sensitive Zones (ESZ) - ESZ1, ESZ2 and ESZ3 based on a scoring system assigned to the states/variants of each of the 8 parameters on a scale of $0-10$, and average score for each grid was calculated. Similarly the average scores of grids of PAs were calculated and ranked in descending order in each state. If the average score of the grid was equal or higher than the lowest rank grid of PAs then it was treated as ESZ 1, and about $25 \%$ of grids having average scores of grids equal to lowest rank grids of PA were treated as ESZ2 and the remaining ones were 
treated as ESZ3. This was based on the stipulation that protected areas $(\mathrm{PA})+\mathrm{ESZ1}$ in each state should not exceed $60 \%$ of the total area and PA+ ESZ1 +ESZ2 should make it $75 \%$ of the total as forest cover. Using an algorithm the grids were assigned to different ESZs[43 and 52]. The report has assigned 41 talukas from 9 districts to the three ESZ categories those either fully or $>50 \%$ by their areas fall within the NWGM and 30 talukas from 11 districts have been assigned to ESZ2 and ESZ3 categories those having $<50 \%$ of their area falling within the NWGM. Of these areas of 4 talukas appear in both the ESZ2 and ESZ3 categories. These are cited under Annexure IV. Guidelines are proposed for sector wise activities for 24 sectors for all the three ESZ categories.

The report has further identified Ecologically Sensitive Localities. These include Lonavla-Khandala; a cluster of 25 villages from Sawantwadi and Dodamarg talukas and has recommended ESAs around the PAs.

It is on record that the Government of India in the Ministry of Environment, Forests, Wildlife and Climate Change (MoEFCC-changed designation from the previous MoEF) has announced that it is processing the HLWG report - here it is not about questioning such decision or debating the merits of the two reports or the differences but to emphasize the fragility of the Western Ghats underwritten by the two reports of which the NWGM is a tract.

\section{The Report of the HLWG}

The HLWG approach for the delineation of ecosensitive area starts with the natural vegetation consisting of major vegetation types. Primarily, the only fine scale, spatially consistent information on plant species distribution for the Western Ghats is the vegetation type map. These vegetation types are generated using multi-spectral remote sensing data in conjunction with suitable ground inventory of plant species. Finally the spatially consistent species surrogate information that vegetation types provide, is used as the basis for estimating landscape level metrics such as biological richness and forest fragmentation.

The HLWG effort for the identification of ecologically sensitive areas (ESAs) based on landscape level indicators have utilized the layers generated from the national project on landscape level biodiversity characterization under the collaborative study of the Department of Space and Department of Biotechnology, founded on multi-season IRS LISS-III data. It provides spatial information on the vegetation types consisting of natural and managed vegetation. The satellite image elements were correlated on ground with the sampling intensity varying from $0.002 \%$ to $0.005 \%$, depending upon the vegetation heterogeneity. Details of the study methodology, sampling technique and biological richness modelling have been published. Besides the remote sensing data, other collateral databases used include phytosociological data collected from 16,578 field sample plots (Out of the 7596 plant species documented 648 species are endemic, 23 are endangered or threatened correctly called the 'Threatened Species' under the IUCN recognized categories of threats[55], 1879 are medicinally important and 2803 are economically important species. The popularly used terminology endangered, rare and threatened (ERT) is incorrect and needs to be discarded). The datasets were collected during 1998-2010 under the Department of Biotechnology and Indian Space Research Organization joint programme that is mentioned earlier.

The project combined the spatial information generated on vegetation types with the species level information and landscape level parameters to generate modelled layers on biological richness and disturbance regimes. The spatial database of these layers have served as the baseline data for habitat suitability assessment, prioritization for micro-scale habitat studies, corridor connectivity and landscape planning, identification of species-rich areas, and conservation methods for protection of rare species.

The geospatial analysis for identification of ESA uses two of the landscape level spatial layers - forest fragmentation and biological richness. The fragmentation layer provides insights into the effects of forest fragmentation on landscape patterns, biodiversity and ecological processes. The biological richness layer identifies areas that should be treated on a priority basis for the conservation of biodiversity.

The landscape indices (biological richness and forest fragmentation), derived from the geospatial analysis of IRS LISS-III satellite data include details on species richness of vegetation, endemicity, ecosystem uniqueness, disturbance indicators, adjacency and patch characteristics. This enabled delineation of ESAs in an objective and scientific fashion at a much finer scale with village as a unit and thus paved the way for actionable and implementable approach for the conservation of ecology and equitable and sustainable development of WG, as envisaged by WGEEP. Wildlife habitats are not explicitly included in the demarcation of ecologically sensitive areas; the 
forested and natural landscapes are the best available fine resolution and spatially consistent proxies in the absence of high resolution data on faunal distributions.

The report has included 2053 villages in 56 talukas of 12 districts as ecologically sensitive areas. The details are cited under Annexure $V$.

It will thus be observed that the core conservation units of the landscape are identified and described with justification. There are proven scientific practices and techniques for addressing their security in a Guide that includes PAs, forests outside the PAs (managed forests) and forested landscapes for the purpose. There are units that have been delineated as ESAs by law with guidelines to take the actions forward and there are two scientific reports of the highest standards that further lay the foundation for defining fragile ecosystem units and provide strategies and actions for their security. What is now needed is, at the risk of repeating, the convergence of multi- agency programmes - the pooling of knowledge, skills, capabilities and resources and mechanisms for synergistic working - with security of ecosystems, habitats and species over the given geographic extent as their common frame of reference. It would appear that new laws or appropriate amendments to the existing laws and policies are a necessity-an improvement based on better scientific knowledge but not dilution. It is also necessary to change the populist and extremely dangerous perception rapidly gaining ground that 'development' is the last word for national happiness without conveniently defining the inclusive nature of 'development' by leaving it to all and sundry to interpret its meaning by the numerous and incompatible vested interests rooted in the irresponsible and tragic statement that environmental and forest clearances are 'hurdles' to development.

The overarching principles for addressing ecological security at the landscape level are enshrined in the concepts and actions under Ecosystem Based Management (EBM)[33]. This approach is tailored for application to various subunits of the landscape. It differs from a single species or a single sector approach to management by engaging complex interactions between the living and non-living environment and people in multiple scales of space and time. The principles of EBM are to sustainably manage both target and non-target species involving a three pronged approach of protection, conservation and restoration of habitat quality to maintain ecosystem functions and services. The features of EBM goals are :

- Emphasizing connectivity within and between systems i.e. attempting connectivity between habitat patches through a network of corridors aiming at large landscapes. This would include PAs and production forests on land and between terrestrial habitats, inland wetlands, estuaries, coasts and the sea.

- Emphasizing protection and restoration of ecosystem structure, functions, and processes

- Focusing for the purpose on the consequences of human actions within a specific ecosystem/ management area

- Incorporating social dimensions of resource use and ecosystem values into management

- Integrating biological, socioeconomic and governance perspectives

- Recognizing the high level of uncertainty and variability in the dynamics of ecosystems

- Reflecting a common vision among stakeholders

- Attempting informed adaptation from learning based on science and local knowledge

With all the proven evidence of modern science heavily in favour of protecting and conserving the remnants of ecosystems, natural habitats and species there still would be sceptics and not surprisingly in majority questioning its wisdom. They would do well to read the disastrous consequences of improvident use of renewable resources chronicled dispassionately, truthfully supported by brilliant and incontrovertible research that spans the history of human societies from the fourth to the twentieth century in different parts of the world in a book that has the title of equal weight - 'Collapse - How societies choose to fail or survive' penned by one of the most erudite scientists of our time-Jared Diamond[56]. 


\section{Annexure I}

\section{Major Forest and Habitat Types in NWGM}

Sub- group/sub-type Distribution

Indicative vegetation

\section{A. Southern Tropical}

Wet Evergreen Forests

$\mathrm{C}_{4}$ West coast tropical evergreen forest
Ratnagiri southwards, RF 1500-5000mm, high humidity, alt. 250-1200m

States: Karnataka, Kerala, Maharashtra, Tamil Nadu
Calophyllum spp., Hopea spp., Machilus macrantha, Aglaia roxburghiana, Caryota urens, Strobilanthes, Leea and canes

\section{A Southern Tropical} Semi- Evergreen Forests
$\mathrm{C}_{2}$ West coast semievergreen forest altissima,

zeylanicum,

$\mathrm{E}_{4}$ Lateritic semievergreen forest
A narrow strip between wet ever green and moist deciduous. Hill slopes,

sometimes plains. Vulnerable to destruction. RF 2000-2500; alt. 450-1050m

States: Kerala, Maharashtra, Karnataka, Goa, Tamil Nadu forests, more or less continuous cover States: Kerala, Karnataka, Maharashtra, Tamil Nadu

On lateritic sites. Xylia xylocarpa is the characteristic species States: Goa, Karnataka, Kerala, Maharashtra, Tamil Nadu
$\mathrm{E}_{3}$ Moist bamboo brakes Locally throughout the SEG and MDD
Terminalia paniculata, Lagerstroemia lanceolata, Artocarpus hirsute, Vitex

Tetrameles nudiflora, Pterocarpus marsupium, Canarium strictum, Cinnamomum

Albizzia odoratissima; bamboos and reeds, Clerodendron, Strobilanthes, Entada phaseoloides, Dioscorea spp.

Bambusa arundinacea

Xylia xylocarpa, Pterocarpus marsupium, Terminalia spp, Bridelia retusa, Calycopteris floribunda, Strychnos nux-vomica, Adhatoda vasica, Holarrhena antidysentrica

\section{B South Indian Moist}

Deciduous Forests
$\mathrm{C}_{1}$ a Very moist teak forests
Low percentage of teak $<10$, very dense EG undergrowth, eastern side of the crest of WG. RF $>2500 \mathrm{~mm}$.

States: Gujarat, Kerala, Maharashtra, Goa, Tamil Nadu.
Terminalia paniculata, Grewia tiliaefolia, Lagerstoemia lanceolata, Dillenia pentagyna, T. bellerica, Tectona grandis, Xylia xylocarpa, Dendrocalamus strictus, Oxytenanthera monostigma, Clerodendrum sp. Kydia calycina, Bambusa arundinacea,

$\mathrm{C}_{2}$ Southernmoist mixed All along the WG, usually in the valleys. Tetrameles nudiflora,T. paniculata, deciduous forest States: Gujarat, Goa, Kerala, Karnataka, Maharashtra, Tamil Nadu

T. tomentosa, Madhuca indica, Dillenia pentagyna, Adina cordifolia, Syzygium cumini, Xylia xylocarpa, Strychnos nuxvomica, Bambusa arundinacea, 
Dendrocalamus strictus, Zyzyphus oenoplia, Z. rugosa, Saccharum spontaneum and other grasses.

${ }_{2} \mathrm{~S}_{1}$ Southern secondary Whole length of WG. Origin attributed moist mixed deciduous to shifting cultivation, livestock grazing forest and fires.

States: Goa, Karnataka, Kerala, Maharashtra, Tamil Nadu
Mangifera indica, Bombax ceiba, Lagerstoemia lanceolata, Schleichera oleosa, Alstonia scholaris, Sterculia villosa, Careya arborea, Feronia limonia, Carissa carandas, Saccharum spontaneum.

${ }_{4}$ C Tropical Freshwater

Swamp Forests

$\mathrm{FS}_{2}$ Tropical hill valley swamp forest
Low crowned branchy trees, dense growth of Calamus.

States: Karnataka, Kerala, Maharashtra, Tamil Nadu
Syzigium spp., Pandanus, Alpinia

Bischoefia javanica, Terminalia speciosa, Terminalia arjuna, Mangifera indica, Syzygium cumini.

4E Tropical riparian

fringing forests

RS Riparian fringing forest
Along the banks of larger streams as a narrow linear strip.

States: Gujarat, Maharashtra, Goa, Karnataka, Kerala and Tamil Nadu

\section{A Southern Tropical} Dry Deciduous Forests

$\mathrm{C}_{3}$ Southern dry mixed deciduous forest
Drier localities and sites. RF 875 to $1500 \mathrm{~mm}$, subjected to annual fires States: Gujarat, Kerala, Karnataka, Maharashtra, Tamil Nadu
Anogeissus latifolia, Terminalia tomentosa, T. chebula, T.bellerica, Hardwickia binata, Zizyphus xylopyrus, Gardenia latifolia, Acacia chundra, Santalum album, Dendrocalamus strictus

\section{A Southern Sub- tropical Broadleaved Hill Forests}

$\mathrm{C}_{2}$ Western subtropical hill forest
Northern WG, Maharashtra above 1000 m. e.g. Mahableshwar. RF 1500-6600mm.

States: Karnataka, Maharashtra
Syzygium cumini, Actiodaphne hookeri, Terminalia chebula, Memecylon sp., Flacourtia latifolia, Canthium dicocium, Pogostemon plectranthoides, Carvia spp., Capparis pedunculosa, Zizyphus rugosa, Pavetta indica.

Source: Champion Sir Harry G. and S.K. Seth 1968 
Annexure II

Protected Areas in NWGM

The Existing and Proposed National Parks, Sanctuaries and Tiger Reserves

\begin{tabular}{|c|c|c|c|c|}
\hline Province & Existing & $\begin{array}{l}\text { Size } \\
\mathrm{Km}^{2}\end{array}$ & Proposed & $\begin{array}{l}\text { Size } \\
\mathrm{Km}^{2}\end{array}$ \\
\hline \multicolumn{5}{|c|}{ National Parks } \\
\hline $05 \mathrm{~A}$ & - & 00.00 & - & 00.00 \\
\hline 05B & - & 00.00 & $\begin{array}{l}\text { Radhanagari* } \\
\text { Koyna* }\end{array}$ & $\begin{array}{l}150.00 \\
150.00\end{array}$ \\
\hline Total & - & 00.00 & 2 & 300.00 \\
\hline
\end{tabular}

Wildlife Sanctuaries

$\begin{array}{lllll}\text { 05A } & \begin{array}{l}\text { Karnala } \\ \text { Phansad } \\ \text { Tansa }\end{array} & 04.48 & \text { Vikhroli } & 07.00 \\ & & 69.79 & \text { Karnala Extension } & 07.52 \\ \text { 05B } & 304.81 & & \\ & \begin{array}{l}\text { Bhimashankar } \\ \text { Chandoli** }\end{array} & 130.78 & \text { Mahableshwar } & 50.00 \\ & \begin{array}{l}\text { Koyana* } \\ \text { Radhanagari }\end{array} & 408.97 & \text { Rajmachi } & 70.00 \\ & \mathbf{7} & 351.16 & \text { Mula Mutha } & 01.00 \\ \text { Total } & \mathbf{1 5 9 3 . 5 4} & \mathbf{5} & \mathbf{1 3 5 . 5 2}\end{array}$

**These have been included in the Sahyadri Tiger Reserve

\section{Tiger Reserves}

$\begin{array}{lllll}\text { 05A and 05B } & \text { Sahyadri } & 732.52 & - & 00.00 \\ \text { Total } & \mathbf{1} & 732.52 & - & \mathbf{0 0 . 0 0}\end{array}$

Source: India's Green Book, Forests and Wildlife, Wildlife Institute of India, Dehradun (2009) 
Annexure III

Western Ghats: District-wise Forest Cover

\begin{tabular}{lccccccc}
\hline District & $\begin{array}{c}\text { Geographical } \\
\text { Area (GA) } \\
\mathbf{k m}^{\mathbf{2}}\end{array}$ & $\begin{array}{c}\text { Very dense } \\
\text { Forest } \\
\mathbf{k m}^{\mathbf{2}}\end{array}$ & $\begin{array}{c}\text { Mod. } \\
\text { Dense forest } \\
\mathbf{k m}^{\mathbf{2}}\end{array}$ & $\begin{array}{c}\text { Open } \\
\text { Forest } \\
\mathbf{k m}^{\mathbf{2}}\end{array}$ & $\begin{array}{c}\text { Scrub } \\
\mathbf{k m}^{\mathbf{2}}\end{array}$ & $\begin{array}{c}\text { Total } \\
\mathbf{k m}^{\mathbf{2}}\end{array}$ & $\begin{array}{c}\text { \% to GA } \\
\text { Dhule }\end{array}$ \\
7189 & 0 & 70 & 251 & 103 & 424 & 5.89 \\
Kolhapur & 7685 & 65 & 1038 & 672 & 88 & 1863 & 24.24 \\
Nandurbar & 5961 & 0 & 418 & 796 & 30 & 1244 & 20.86 \\
Nashik & 15530 & 0 & 351 & 738 & 319 & 1408 & 9.06 \\
Pune & 15643 & 0 & 757 & 975 & 493 & 2225 & 14.22 \\
Raigarh & 7152 & 13 & 1248 & 1603 & 70 & 2934 & 41.02 \\
Ratnagiri & 8208 & 33 & 1911 & 2255 & 2 & 5001 & 51.16 \\
Sangli & 8574 & 0 & 95 & 49 & 156 & 300 & 3.49 \\
Satara & 10480 & 119 & 569 & 588 & 365 & 1641 & 15.65 \\
Sindhudurg & 5207 & 89 & 1372 & 1112 & 47 & 2620 & 50.31 \\
Thane & 9558 & 0 & 1281 & 1631 & 222 & 3134 & 32.78 \\
Total (11) & 101187 & 319 & 9110 & 10670 & 1895 & 22794 & 22.52
\end{tabular}

Source: India State of Forest Report 2013 


\section{Annexure IV}

Assignment of Talukas within the NWGM to the various Ecological Sensitive Zones Categories as per the WGEEP Report (I)

\begin{tabular}{|c|c|c|c|}
\hline District & Talukas in ESZ1 & Talukas in ESZ2 & Talukas in ESZ3 \\
\hline \multicolumn{4}{|c|}{ Talukas with $>50 \%$ area within the NWGM } \\
\hline Ahmednagar & & Parner & Akola \\
\hline Kolhapur & $\begin{array}{l}\text { Radhanagiri, Gargoti, Shahuwadi, } \\
\text { Panhala, Bavda }\end{array}$ & & $\begin{array}{l}\text { Ajra, Changad, } \\
\text { Gadhinglaj }\end{array}$ \\
\hline Nandurbar & & & Navapur \\
\hline Nashik & Nashik, Peint, Dindori & Surgana & Igatpuri \\
\hline Pune & Ghod,Paud, Bhor, Wadgaon & & Junnar, Sasvad \\
\hline Raigarh & $\begin{array}{l}\text { Mhasla, Pali, Poladpur, Roha, } \\
\text { n.a. (1657), Pen, Mahad, } \\
\text { n.a. (1634) }\end{array}$ & & Mangaon, n.a. (1572) \\
\hline Ratnagiri & Devrukh, Chiplun & Mandangarh & Khed \\
\hline Satara & $\begin{array}{l}\text { Medha, Patan, } \\
\text { Mahabaleshwar, Wai }\end{array}$ & Koregaon & Vaduj, Dahivadi \\
\hline Sindhudurg & Kankauli, Savantvadi & & \\
\hline Thane & $\begin{array}{l}\text { Murbad, Mokhada, } \\
\text { n.a. (1482), Jawahar }\end{array}$ & & Shahapur \\
\hline
\end{tabular}

Talukas with $<50 \%$ area within the NWGM

$\begin{array}{lll}\begin{array}{l}\text { Nashik } \\ \text { Sindhudurg } \\ \text { Sangli }\end{array} & \begin{array}{l}\text { Kalvan, Chandvad, Sinnar } \\ \text { Kudal, Vaibhavvadi }\end{array} & \text { Chandvad, Sinnar, Satana } \\ \text { Shirala } & & \begin{array}{l}\text { Atpadi, Kavathe, Mahankal, } \\ \text { Tasgaon, Vite }\end{array} \\ \text { Dhule } & & \text { Bhivandi } \\ \text { Ratnagiri } & & \text { Sakri } \\ \text { Solapur } & & \text { Dapoli, Guhagar } \\ \text { Pune } & \text { Rajgurunagar, n.a. (1612) } & \text { Malsiras, Sangole } \\ & & \begin{array}{l}\text { Rajgurunagar, n.a. (1612), } \\ \text { Kolhapur }\end{array} \\ \text { Ahmednagar } & \text { Sangamner } & \text { Kagal } \\ \text { Satara } & & \text { Sangamner, Ahmednagar } \\ & & \text { Karad, Shirwal, Phaltan, } \\ & & \text { Satara }\end{array}$


The Numbers of Villages Assigned to the Ecologically Sensitive Status in the NWGM as per the Report of the HLWG Committee (Volume I)

\begin{tabular}{lcc}
\hline District & Numbers of talukas & Numbers of villages \\
\hline Ahmednagar & 1 & 42 \\
Dhule & 1 & 5 \\
Kolhapur & 7 & 188 \\
Nandurbar & 1 & 2 \\
Nashik & 8 & 157 \\
Pune & 9 & 336 \\
Raigarh & 7 & 356 \\
Ratnagiri & 5 & 292 \\
Sangli & 1 & 24 \\
Satara & 6 & 201 \\
Sindhudurg & 5 & 192 \\
Thane & 5 & 261 \\
Total (12) & $\mathbf{5 6}$ & $\mathbf{2 0 5 6}$
\end{tabular}

\section{References}

1. India State of Forest Report 2013, Forest Survey of India, Dehradun

2. WII 2012: India's Green Book: Forests and Wildlife, Wildlife Institute of India, Dehradun

3. Misra R. 1968 Ecology Workbook, Oxford and $\mathrm{IBH}$

4. Sawarkar V.B. 2005 Planning wildlife Management in Protected Areas and Managed Landscapes, Natraj, Dehradun

5. Ministry of Environment and Forests, Government of India 1988, National Forest Policy 1988

6. Ministry of Environment and Forests, Government of India 1972, The Wildlife (Protection) Act 1972 (53 of 1972), Universal Law Publishing Co. Pvt. Ltd. 2009

7. Anon 1994: Guidelines for PA management categories. CNPPA with assistance of WCMC. IUCN, Gland, Switzerland and Cambridge, UK

8. Dudley N 2008: Guidelines for Applying PA Management Categories, IUCN, Gland, Switzerland

9. UNESCO 1912 http://whc.unesco.org/en/list/ 1342

10. Decker D.J., Krasny M.E., Goff G.R., Smith C.R. and Gross D.W. 1991 Challenges in Conservation of Biological Resources, A Practitioner's Guide, Westview Press, Oxford

11. Harris L.D. 1984 The Fragmented Forest, the island biogeography theory and the preservation of biotic diversity, Univ. of Chicago Press

12. Rajesh Gopal, Sinha PR, Mathur VB, Jhala YV and Q Qureshi 2007, Guidelines for Preparation of Tiger Conservation Plan. A technical document of the National Tiger Conservation Authority, Ministry of Environment and Forests, Government of India. NTCA/01/07

13. Ministry of Environment and Forests, Government of India 1986, The Environment (Protection) Act 1986, 29 of 1986

14. Ministry of Environment and Forests, Government of India 1980, The Forest (Conservation) Act 1980

15. Ministry of Law and Justice (Legislative Department) 2002, The Biological Diversity Act 2002

16. Ministry of Environment and Forests, Government of India, 2010, The Wetland (Conservation and Management) Rules 2010

17. Ministry of Environment and Forests (Department of Forests and Wildlife) Government of India, 2011, Coastal Regulation 
Zone Notification 2011

18. Ministry of Environment and Forests, Government of India, 2006, National Environment Policy 2006

19. Ministry of Agriculture (Department of Animal Husbandry and Dairying) 2004, Comprehensive Marine Fishing Policy 2004

20. Ministry of Environment and Forests, Government of India, 1992, National Conservation Strategy and Policy Statement on Environment and Development 1992

21. Ministry of Environment and Forests, Government of India, 2002, National Wildlife Action Plan 2002-2016

22. Ministry of Environment and Forests, Government of India, 2000, National Biodiversity Strategy and Action Plan India, Guidelines and Concept Papers, 2000

23. Ministry of Environment and Forests, Government of India, 2007, Protection, Development, Maintenance, and Research in Biosphere Reserves in India, Guidelines and Proformae 2007

24. Ministry of Environment and Forests, Government of India, 2009, Guidelines for Integrated Management Action Plan for Wetlands, Mangroves and Corals, 2009

25. Decker D.J., Krasny M.E., Goff G.R., Smith C.R. and Gross D.W. 1991Challenges in Conservation of Biological Resources, A Practitioner's Guide, Westview Press, Oxford

26. Nautiyal S and AK Kaul 2003 Non-Timber Forest Products of India, Jyoti Publishers and Distributors, Dehradun

27. Thomas J.W. (Ed) 1979 Wildlife Habitats in Managed Forests. The Blue Mountains of Oregon and Washington, USDA Forest Service, Agricultural Handbook No. 533

28. Hunter M.L. (Jr.) 1990 Wildlife, Forests and Forestry - the principles of managing forests for biological diversity, Prentice Hall, NJ

29. Harris L.D. 1984 The Fragmented Forest, the island biogeography theory and the preservation of biotic diversity, Univ. of Chicago Press

30. IPCC (2007). Synthesis Report. Contribution of Working Groups I, II and III to the Fourth Assessment Report of the Intergovernmental Panel on Climate Change [Core Writing Team, Pachauri, R.K and Reisinger, A. (Eds.)]. IPCC, Geneva, Switzerland, $104 \mathrm{pp}$

31. Mathur P.K, J.F. Lehmkuhl, and V.B.Sawarkar (Tech. Coordinators) 2002, Management of
Forests in India for Biological Diversity and Forest Productivity - A New Perspective, WIIUSDA Collaborative Project Report, Vol. I Concepts, Approaches and Project Overview, WII

32. Morrison M.L., Marcot B.G. and Mannan R.W. 1998 Wildlife Habitat Relationships: Concepts and Applications. The University of Wisconsin Press, Madison

33. Sriyanie Miththapala, Vishwas Sawarkar, Pramod Krishnan, and Madhavi Malalgoda Ariyabandu 2012, A Toolkit for Integrating Disaster Risk Reduction and Climate Change Adaptation into Ecosystem Management of Coastal and Marine Areas in South Asia; United Nations Office for Disaster Risk Reduction, Asia and Pacific, Thailand and the United Nations Development Programme, India Pp 154

34. Myers, N., R.A. Mittermeier, C.G. Mittermeier, G.A.B. Da Fonseca, and J. Kent. (2000) "Biodiversity Hotspots for Conservation Priorities." Nature 403:853-858

35. Rodgers Alan W., Hemendra S. Panwar and Vinod B. Mathur 2002: Wildlife Protected Area Network in India: A Review (Executive Summary), Wildlife Institute of India, Dehradun

36. Daniel Ranjit R.J. 2003: Biodiversity of the Western Ghats : An Overview In ENVIS Bulletin : Wildlife and PAs; Conservation of Rainforests in India, A.K. Gupta, Ajith Kumar and V. Ramakantha (Eds) Vol 4 (1) 25-40

37. Bawa Kamal, Arundhati Das, Jagdish Krishnaswamy, K.Ullas Karanth, N. Samba Kumar and Madu Rao 2007: Ecosystem Profile of Western Ghats. www.cepf.net/western ghats/ ecosystem profile

38. Briggs, JC (2003) the biogeographic and tectonic history of India. Journal of Biogeography, 30:381388

39. Champion H.G. and Seth S.K. 1968 A Revised Survey of the Forest Types of India, Govt. of India

40. Ministry of Environment and Forests, Government of India 2011, Guideline for declaration of Eco-sensitive Zones around National Parks and Wildlife Sanctuaries \{F.No. 19/WL-I (pt.) 09 February 2011\}

41. Johnsingh AJT, Atul Joshi, R. Raghunath, Anand MO, MD Madhusudan 2010 : Towards a regional conservation strategy for Western Ghats: an assessment of habitat quality, connectivity, distribution, of large mammals and humanwildlife conflicts-A report on the activities and 
studies carried out in Sahyadri during 2007-2009. Nature Conservation Foundation, Mysore. Pp.45

42. Anon: Western Ghats (Sub-Cluster nomination) UNESCO World Heritage Centre. www.whc.unesco.org

43. Western Ghats Ecology Expert Panel Part I 2011: Report of theWestern Ghats Ecology Expert Panel Part I submitted to the Ministry of Environment and Forests, Government of India. Pp 150

44. Kulkarni Jayant and Prachi Mehta 2013: A Study of Status, Distribution and Dynamics of Private and Community Forests in Sahyadri-Konkan Corridor of Maharashtra Western Ghats. Technical Report submitted to CEPF-ATREE. Wildlife Research and Conservation Society, Pune. Pp. 156

45. Watwe Aparna 2013: Status review of rocky plateaus in the northern Western Ghats and Konkan region of Maharashtra, India with recommendations for conservation and management. Journal of Threatened Taxa, www.threatenedtaxa.org, 5(5):3935-3962, March 13 2013; Western Ghats Special Series, Critical Ecosystems Partnership Fund.

46. Watwe Aparna 2013: Conservation Value of Zenda Plateau (Pers.Comm.)

47. Ministry of Environment and Forests, Government of India, 2001, notification for Mahableshwar and Panchgani as ESA, dated January 17, 2001

48. Ministry of Environment and Forests, Government of India, 2003, notification for Matheran as ESA, dated February 04, 2003
49. Ministry of Environment and Forests, Government of India, 1996, notification for Dahanu taluka as ESA, dated December 19, 1996 (Amended up to June 19, 2001)

50. Ministry of Environment and Forests, Government of India (Department of Forests and Wildlife) 1989, notification for Murud-Janjira as ESA, dated January 06, 1989

51. Institute of Environmental Research and Education, Bharti Vidyapeeth 2010, Current Ecological Status and Identification of Ecologically Sensitive Areas in the Northern Western Ghats Pp 164

52. Western Ghats Ecology Expert Panel Part II 2011 : Report of theWestern Ghats Ecology Expert Panel Part I submitted to the Ministry of Environment and Forests, Government of India. Pp 327

53. Report of the High Level Working Group on Western Ghats 2013, Volume I, Ministry of Environment and Forests, Government of India, Pp 149

54. Report of the High Level Working Group on Western Ghats 2013, Volume II, Ministry of Environment and Forests, Government of India, Pp 60 plus variously numbered pages of Appendices

55. IUCN 2001, Species Survival Commission- Red List Categories and Criteria, 51 ${ }^{\text {st }}$ Meeting of the Council, Gland, Switzerland

56. Diamond Jared 2005, Collapse-How Societies Choose to Fail or Survive. Penguin Books, London and New York. 